\title{
УДK $577,213.3$
}

\author{
C. Б. Арбузова
}

\section{НЕ МНОГО ЛИ ВНИМАНИЯ УДЕЈЕНО ЯДЕРНОМУ ГЕНОМУ В ІІТОГЕНЕЗЕ БОЛЕЗНИ ДАУНА? НОВАЯ ГИПОТЕЗА}

Выдөинута аипотеза о влиянии мутаций в митохондриалькой ДНК ма патогенез трисомий 21, обтясняющая повьшение риска болезни Дауна с возрастом матери, связь со злохаяественными заболеваниями, аутоимнукными процессами, повторные случаи БД, сочетание с другой патологией, происхождекие отцовской хромосомы 21.

Результаты изучения физического и химического мутагенеза, действия вирусов как факторов, вызывающих нерасхождение хромосом при регулярной трисомни 21-й хромосомы, неоднородны и противоречивы. Связь внешних факторов с хромосомной патологией, вероятно, не носит причинно-следственного характера, а является отражением более сложной ситуации.

Давая оценку цитогенетнцеским особенностям у родителей (повышенная частота маркерных хромосом, перицентрические инверсии хромосомы 9, хромосомные перестройки), сочетанию болезни Дауна с другой патологией, в том числе у сибсов, родителей, родственников, счнтаем, что эти события должны пронсходить чрезвычайно редко, если они возникают случайно и незавнсимо.

Предложена гипотеза о влиянии мутаций в митохондриальной ДНК (мтДНК) на патогенез трисомии 21, объясняющая возрастание риска трисомин 21 с возрастом матери, связь со злокачественными заболеваниями, аутоиммунными процессами, повторные случаи болезни Дауна, сочетанне с другой патологией.

Отцовское происхождение 21-й хромосомы объясняется взаимодействием митохондриального и ядерного геномов, первоначальным получением гипотетического фактора отцом с цитоплазмой его матери и последующей инсерцией мтДНҚ в ядерный геном.

Гипотетический фактор, наследуемый по материнской линии, мо* жет быть представлен мутантной цитохромоксндазой С или другим ферментом, связанным с продукцией радикалов кислорода. На биохимическом уровне это проявляется в разбалансировке окислительной системы клетки, возможно, в зависимости от соотношения пормальной и мутантной мтДНК. Патологическими агентами могут служить радикалы кислорода, повышенная концентрация которых приводит к повреждению ядерной ДНК.

Мутацин присутствуют у матери, могут накапливаться у нее, проявляться или не проявляться клилически, У такой клинически здоровой женщины могут родиться здоровые дети либо дети с генетическнми заболеваниями, но все они носители гипотетического фактора. По мужской линии цепь обрывается, увеличивая долю женских носителей.

\section{B. Apбy308a}

\section{ЧИ НЕ ЗАБАГАТО УВАГИ ПРИДІЛЕНО ЯДЕРНОМУ ГЕНОМОВІ В ПАТОГЕНЕЗІ СИНДРОМУ ДАУНА? НОВА ГІПОТЕЗА}

$\mathrm{Pe} 3$ 10 M

Висунуто гіпотезу щодо впливу мутацій в мітохондріальній ДНК на патогенез трисомї 21, яка пояснюе збільшення ризику синдрому Дауна, пов'язаного з віком матері, эв'язок із злоякісними хворобамн, аутоімуними процесами, повторні винадки снндрому Дауна, поєднання 3 іншою патологією, походження батьківської хромосоми 21.

Донецк, межобл. мед.-генет, центр

Получено 04.01 .95

(C. Б. АРБУЗОВА, 1995 